\title{
Üretici Bakış Açısıyla Çorum İlinde Makarnalık Buğdayın Dünü, Bugünü ve Geleceği
}

\author{
Past, Present and Future of Durum Wheat in Çorum within a Producer's perspective
}

\section{Rahmi TAŞCI ${ }^{*}$}

Merve BOLAT ${ }^{2}$

Belma ÖZERCAN ${ }^{3}$

Sinem TARHAN ${ }^{4}$

Tuğçe HAMARAT ${ }^{5}$

Sevinç KARABAK ${ }^{6}$

Selda ARSLAN ${ }^{7}$

\section{Zeki BAYRAMOĞLU ${ }^{8}$}

1,2,3,4,5,6,7 Tarla Bitkileri Merkez Araştırma Enstitüsü /

Tarım Ekonomisi Bölümü / Ankara

${ }^{8}$ Selçuk Üniversitesi Ziraat Fakültesi Tarım

Ekonomisi Bölümü / Konya

*Sorumlu yazar: rahmi.tasci@tarimorman.gov.tr

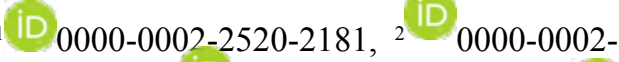
$2393-141 X,{ }^{3}$ 0000-0003-3492-8192, ${ }^{4}$ 0000-0002-3009-0815, 5 iD 0000-0002-1830$5406,{ }^{6}$ 0000-0001-8662-6175, ${ }^{\text {D }} 0000$ 0002-2387-9447, 8 iD 0000-0003-3258-3848

Destekleyen Kurum:

Tarim ve Orman Bakanlığı Tarımsal Araştırmalar ve Politikalar Genel Müdürlüğü

Proje Numarası: TAGEM/TEAD/15/A15/P02/001

Gönderilme Tarihi:

9 Ekim 2020

Kabul Tarihi

\section{ÖZET}

$\mathrm{Bu}$ çalışmanın amacı; Çorum ilinde makarnalık buğday üretimi yapan tarım işletmelerinin, makarnalık buğday üretimine dair mevcut durum ve geleceğe yönelik beklentilerinin incelenmesidir. Türkiye'nin makarnalık buğday üretiminde uzun yıllardır önemli illerinden birisi olan Çorum ilinde üreticilerin makarnalık buğday ekim alanlarının yıllar itibarıyla azaldığı görülürken, üreticiler tarafından en fazla tanınan ve en geniş alanlarda ekilişi gerçekleştirilen makarnalık buğday çeşidinin Çeşit- 1252 olduğu belirlenmiştir. Makarnalık buğdayları hammadde olarak kullanan makarna ve bulgur fabrikalarının Çorum ilinde faaliyet göstermesi; Çorum ilinde makarnalık buğday üretiminin sürdürülebilmesi açısından önemli bir faktör olarak görülmektedir. Üreticilerin makarnalık buğday çeşit tercihinde; verimi fazla olan, yörenin iklim ve toprak yapısına uygun ve kolay pazarlanabilen çeşitleri tercih ettiği gözlenirken, Çorum ilinde makarnalık buğday satış fiyatlarının, uzun yıllar boyunca ekmeklik buğday satış fiyatlarından fazla olduğu belirlenmiştir. Makarnalık buğday islah programlarının planlanmasında ve yürütülmesinde çeşit geliştiren kurum / kuruluşlar ile tarıma dayalı sanayicilerin ve üreticilerin de ihtiyacına 
yönelik yeni çeşit geliştirme işbirliklerinin arttırılması ile birlikte yeni geliştirilen ve yöreye uygun makarnalık buğday çeşitlerinin ve üretim tekniklerinin üreticiye ulaştırılma çalışmalarının artarak sürdürülmesi gereklidir. Bununla birlikte gelecek yıllardaki makarnalık buğday ekim alanlarında ve üretim miktarında azalmanın olabileceği de göz önünde bulundurularak, özellikle Güneydoğu Anadolu ve Orta Anadolu Bölgelerinde makarnalık buğday üretim alanları belirlenerek, bu alanlarda makarnalık buğdaya ayrı bir tarımsal destekleme modeli önerilebilir.

Anahtar kelimeler: Çorum, makarnalık buğday, buğday üretimi, buğday pazarlama.

\section{ABSTRACT}

The aim of this study is; to examine of the current situation and future expectations of the agricultural enterprises producing durum wheat in Çorum province. Çorum province for many years, while one of Turkey's leading producers of durum wheat production is seen that the durum wheat area decreased over the years. It has been determined that the most widely known durum wheat variety by producers who cultivate durum wheat is Çeşit-1252. The fact that pasta and bulgur factories, which use durum wheat as a raw material, operate in Çorum, is seen as an important factor in the continuation of durum wheat production in this province. While producers prefer the durum wheat variety, they have preferred varieties with high yield, suitable for the climate and soil structure of the region and easily marketable. In addition, it has been determined that the sales prices of durum wheat in Çorum province have been higher than the sales prices of bread wheat for many years. In the planning and execution of durum wheat breeding programs, it is necessary to increase the cooperation with the institutions / organizations that develop varieties and the development of new varieties for the needs of agricultural industrialists and producers. In addition, it is necessary to continue increasing efforts to deliver the newly developed durum wheat varieties and production techniques suitable for the region to the producers. However, taking into account the possibility of a decrease in future durum wheat cultivation areas and production amount, especially in the Southeastern Anatolia and Central Anatolia Regions, durum wheat production areas can be determined and a separate agricultural support model can be proposed for these areas.

Keywords: Çorum, durum wheat, wheat production, wheat marketing.

\section{GIRİŞ}

Dünyada, tarımı yapılan ürünlerin \%41'ini tahıllar oluştururken, buğday da, tahıllar içinde \%48'lik önemli bir kısmı oluşturmaktadır (FAO, 2020). İnsan beslenmesinde kullanılan kültür bitkileri arasında dünyada ve Türkiye'de ekiliş alanı ve üretim bakımından ilk sırada yer alan buğdayın en fazla yetiştirilen tahıl türlerinden biri olmasının nedenleri arasında; çok geniş bir adaptasyon kabiliyetine sahip olması, dane olarak hasat edilen ürünün kolay saklanmas1, depolanması ve işlenmesi gelmektedir (Süzer, 2012). Türkiye'de tarım yapılabilir alan içinde tahıllar \%49'luk bir pay almakta olup, ,buğday da toplam tahıl alanı içinde \%24'lük 
pay almaktadır. (TÜİK, 2020). Birçok ülkede olduğu gibi Türkiye'de de buğday temel gıda maddesidir. Ekmek çeşitleri başta olmak üzere makarna, bulgur, erişte, kuskus, bisküvi, kraker, gofret, kek, simit, poaça, kahvaltılık gevrekler, çerez gidalar, nişasta, vital gluten ve nişasta bazlı şekerler gibi birçok gıdanın üretiminde kullanılmaktadır. Buğdayın öğütülmesi nomisi kadar açıklıkla bilinmemesine rağmen günümüzde makarnalık buğday ekonomisi de türevlerini içerecek şekilde bilinir hale gelmiştir (Bayaner ve ark,. 2010). Türkiye'de makarnalık buğday en fazla bulgur, irmik ve makarna sektörü tarafindan değerlendirilme olup, Türkiye makarnalık buğday üretimi miktar olarak makarna fabrikalarının ihtiyaçlarını karşılamaya

Çizelge 1. Türkiye geneli ve Çorum ilinde yıllar itibari ile buğday ekim alanları (bin da)

\begin{tabular}{|c|c|c|c|c|c|c|c|c|c|}
\hline \multirow{2}{*}{ Yillar } & \multicolumn{3}{|c|}{ Türkiye } & \multicolumn{3}{|c|}{ Çorum } & \multicolumn{3}{|c|}{ Çorum / Türkiye (\%) } \\
\hline & Ekmeklik & Makarnalık & Toplam & Ekmeklik & Makarnalık & Toplam & Ekmeklik & Makarnalık & Toplam \\
\hline 2015 & 65.931 & 12.738 & 78.669 & 1.875 & 340 & 2.215 & 2,84 & 2,67 & 2,82 \\
\hline 2016 & 64.333 & 12.387 & 76.719 & 1.859 & 293 & 2.152 & 2,89 & 2,36 & 2,80 \\
\hline 2017 & 64.320 & 12.369 & 76.689 & 1.965 & 262 & 2.228 & 3,06 & 2,12 & 2,91 \\
\hline 2018 & 60.972 & 12.021 & 72.993 & 1.820 & 257 & 2.076 & 2,99 & 2,14 & 2,85 \\
\hline 2019 & 57.508 & 10.956 & 68.463 & 1.721 & 237 & 1.958 & 2,99 & 2,16 & 2,86 \\
\hline
\end{tabular}

Kaynak: TUİK 2020

sonucunda elde edilen kepek ise, çoğunlukla yem sanayinde değerlendirilmektedir (Hoseney 1994; Elgün and Ertugay 1995; Bushuk 1998). Tahıl ve özellikle buğday üretimi, Türkiye gibi gelişmekte olan ülkelerde nüfusun kalori ve protein ihtiyacinın yarısından fazlasının karşılanmasında son derece önemli bir üründür (Demirbaş ve Atış, 2005). Makarnalık buğdayların yüzyıllardan beri yetiştirildikleri Türkiye ve Ortadoğu ülkeleri, bu ürünlerin geleneksel üretici ülkeleri olarak bilinmektedir (Yağdı ve Ekingen, 1993). Türkiye' de yakın zamana kadar makarnalık buğday ekonomisi, buğday eko- yeterli olmakla birlikte, kaliteli hammaddeye gereksinim duyulmaktadır. (Yalvaç ve ark., 2010).

Çorum; Orta Karadeniz Bölgesinde yer alan, coğrafi konumu itibariyle İç Anadolu'yu Karadeniz'e, Doğu Anadolu'yu Batı'ya bağlayan işlek yol güzergahında bulunan, ekonomisinde genellikle bitkisel ve hayvansal üretim ile tarıma dayalı sanayinin yanında, tuğla kiremit ve makina sanayisi gibi endüstriyel iş kollarında da güçlü olan bir ilimizdir. Çorum büyük oranda kuru alanlarda buğday üretimi yapılan ve Türkiye makarnalık buğday üretiminde uzun yıllardır 
önemini koruyan bir ildir.

Türkiye ve Çorum ilinde yıllar itibari ile ekmeklik ve makarnalık buğday ekim alanları Çizelge 1 'de gösterilmiş olup, Türkiye genelinde ve Çorum ilinde son 5 yıl içinde ekmeklik ve makarnalık buğday ekim alanlarının giderek azaldığı görülmektedir. Çorum ili, makarnalık buğday ekim alanlarında 2015 yılında Türkiye'nin \%2,67'sini karşılarken, 2019 yılında bu oranın \%2,16’ya düştüğü görülmektedir.

Türkiye'nin makarnalık buğday üretiminin yıllara göre değişen oranlarda olmak üzere ortalama \% 2'sinin Çorum ilinden sağlandığı görülmektedir (Çizelge 2). 2020 yılı TÜİK verilerine göre 2019 y1lında Çorum ilinin makarnalık buğday üretim miktarı 60.219 ton olarak gerçekleşmiş olup söz konusu üretim miktarıTürkiye makarnalık buğday üretiminin \%1,91'ine karş1lık gelmektedir. .

2019 üretim yılında Türkiye'nin makarnalık buğday ekiliş alanlarının \%2,16'sını ve makarnalık buğday üretim miktarının \%1,91'ini karşılayan Çorum ilinde, makarnalık buğday verimlerinin Türkiye ortalamasının altında olduğu görülmektedir (Çizelge 3). 2015-2019 yılları arasında Türkiye'de makarnalık buğday verim ortalamas1 $303 \mathrm{~kg} / \mathrm{da}$ olarak bildirilirken, Çorum ilinde ise $254 \mathrm{~kg} / \mathrm{da}$ olarak belirlenmiş ve dekarda Türkiye ortalamasından $49 \mathrm{~kg}$ daha az verim alındığı görülmüştür .

\section{MATERYAL VE YÖNTEM}

Türkiye'dekimakarnalık buğday ekim alanlarının yaklaşık \%3,0’ünün karşılandığı, makarnalık buğday ekiliş alanı, üretimi, pazarlama kanalları ve il genelinde makarna ve bulgur fabrikalarının mevcudiyeti bakımından uzun yıllardır makarnalık buğday açısından önemini koruyan Çorum ili (Şekil 1) gayeli olarak belirlenmiş ve Tarım ve Orman Bakanlığı veri tabanından elde edilen makarnalık buğday üreten işletmelerin makarnalık buğday ekiliş alanları (dekar) veri seti üzerinden örnekleme yapılmıştır. Örnek çekilecek evrenin varyasyon katsayısı 0,75 'in

Çizelge 2. Türkiye ve Çorum ilinde yıllar itibari ile buğday üretim miktarları (bin ton)

\begin{tabular}{|c|c|c|c|c|c|c|c|c|c|}
\hline \multirow{2}{*}{ Yillar } & \multicolumn{3}{|c|}{ Türkiye } & \multicolumn{3}{|c|}{ Çorum } & \multicolumn{3}{|c|}{ Çorum / Türkiye $(\%)$} \\
\hline & Ekmeklik & Makarnalık & Toplam & Ekmeklik & Makarnalık & Toplam & Ekmeklik & Makarnalık & Toplam \\
\hline 2015 & 18.500 & 4.100 & 22.600 & 536 & 87 & 623 & 2,90 & 2,11 & 2,76 \\
\hline 2016 & 16.980 & 3.620 & 20.600 & 531 & 77 & 608 & 3,12 & 2,14 & 2,95 \\
\hline 2017 & 17.600 & 3.900 & 21.500 & 516 & 65 & 581 & 2,93 & 1,67 & 2,70 \\
\hline 2018 & 16.500 & 3.500 & 20.000 & 451 & 64 & 515 & 2,73 & 1,83 & 2,58 \\
\hline 2019 & 15.850 & 3.150 & 19.000 & 443 & 60 & 503 & 2,79 & 1,91 & 2,65 \\
\hline
\end{tabular}

Kaynak: TUİK 2020 
Çizelge 3. Türkiye geneli ve Çorum ilinde y1llar itibarıyla buğday verimleri (kg/da)

\begin{tabular}{|c|c|c|c|c|c|c|}
\hline \multirow{2}{*}{ Y1llar } & \multicolumn{2}{|c|}{ Türkiye } & \multicolumn{2}{c|}{ Corum } & \multicolumn{2}{c|}{ Corum fark } \\
\cline { 2 - 7 } & Ekmeklik & Makarnalık & Ekmeklik & Makarnalık & Ekmeklik & Makarnalık \\
\hline 2015 & 281 & 322 & 286 & 255 & +5 & -67 \\
\hline 2016 & 266 & 297 & 285 & 265 & +19 & -32 \\
\hline 2017 & 274 & 316 & 263 & 248 & -11 & -68 \\
\hline 2018 & 271 & 291 & 248 & 249 & -23 & -42 \\
\hline 2019 & 276 & 288 & 257 & 254 & -19 & -34 \\
\hline Ortalama & $\mathbf{2 7 4}$ & $\mathbf{3 0 3}$ & 268 & 254 & -6 & -49 \\
\hline
\end{tabular}

Kaynak: TUIK 2020

üzerinde olduğu için, evrene ait örnek işletme sayısının bulunmasında tabakalı tesadüfî örnekleme yöntemi kullanılmıştır (Çizelge 4).

Tabakalı tesadüfi örnekleme yöntemine göre çalışılacak örnek sayısı aşağıdaki formül kullanılarak hesaplanmıştır (Yamane, 1967).

$$
\mathrm{n}=\frac{\sum\left(\mathrm{N}_{\mathrm{h} .} \mathrm{S}_{\mathrm{h}}\right)^{2}}{\mathrm{~N}^{2} \mathrm{D}^{2}+\sum \mathrm{N}_{\mathrm{h} .} \mathrm{S}_{\mathrm{h}}^{2}}
$$

$\mathrm{D}^{2}=\mathrm{d}^{2} / \mathrm{z}^{2}$

Formülde;

n : Örnek sayısı,

$\mathrm{N}$ : Popülasyondaki işletme sayısı,

$\mathrm{N}_{\mathrm{h}}$ : h’ıncı tabakadaki işletme sayısı,

$\mathrm{S}_{\mathrm{h}}^{2}:$ h'1nc1 tabakanın varyans1,

d : Popülasyon ortalamasından izin verilen

hata pay1,

Z : Hata oranına göre standart normal dağılım Çizelgesindeki $\mathrm{z}$ değerini ifade etmektedir. Örnek hacminin belirlenmesinde $\% 10$ hata payı ile $\% 90$ güven sınırları içinde çalışılmıştır. Belirlenen örnek hacminin tabakalara dağıtılmasında "Neyman Yöntemi” kullanılmış ve $\mathrm{NhSh}_{*} \mathrm{n} / \Sigma \mathrm{N}_{\mathrm{h}} \mathrm{S}_{\mathrm{h}}$ formülü kullanılmıştır.
Çorum ilinin toplam buğday ekili alanlarının $\% 25$ 'ini ve özellikle makarnalık buğday ekili alanlarının \% 55'ini oluşturan İskilip ve Bayat ilçelerine bağlı 22 farklı köy ve mahallede makarnalık buğday üreten 97 tarım işletmecisi ile araştırma ekibi tarafindan 2019 yılı Nisan ayında yüz yüze görüşülerek anket çalışmaları tamamlanmıştır.

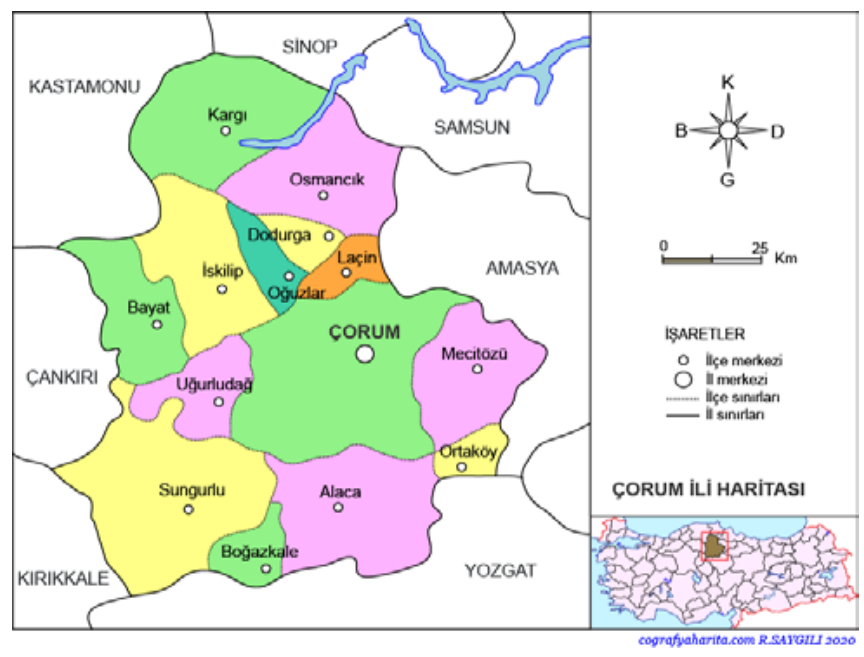

Şekil 1. Çorum ili haritası

Çizelge 4. İşletme anket sayılarının tabakalara göre dağılımı

\begin{tabular}{|l|l|l|l|l|l|l|l|l|l|l|l|l|l|l|}
\hline \multicolumn{3}{|c|}{$0-25(\mathrm{da})$} & \multicolumn{3}{c|}{$26-75(\mathrm{da})$} & \multicolumn{3}{c|}{$76-200(\mathrm{da})$} & \multicolumn{3}{c|}{$201-+(\mathrm{da})$} & \multicolumn{3}{c|}{ Toplam } \\
\hline $\mathbf{N}$ & $\mathbf{n}$ & $\mathbf{C . V}$. & $\mathbf{N}$ & $\mathbf{N}$ & $\mathbf{C . V}$. & $\mathbf{N}$ & $\mathbf{n}$ & $\mathbf{C . V}$. & $\mathbf{N}$ & $\mathbf{n}$ & $\mathbf{C . V}$. & $\mathbf{N}$ & $\mathbf{N}$ \\
\hline 10.113 & 12 & 33 & 13.431 & 42 & 31 & 4.540 & 32 & 28 & 524 & 11 & 33 & 28.608 & 97 \\
\hline
\end{tabular}


Çorum ili makarnalık buğday ekim alanı ve üretim miktarının beş yıllık gelecek dönem tahminleri için 15 yıllık zaman serisi verileri kullanılmıştır. Tahminlerin yapılmasında Üstel Düzleştirme Yöntemlerinden Çiftli Üstel Düzeltme Yöntemi (Holt) kullanılmıştır. Bu yöntem trende sahip ve mevsimsel değişimlerin yaşanmadığı verilerin tahminleri için kullanılan bir yöntem olup sahip olunan verilerin son dönemlerine daha fazla ağırlık verilerek tahminler yapılmaktadır (Anonim, 2016/a; Yağımlı ve Ergin 2017).

Ortalama: $\mathrm{At}=\alpha \mathrm{Yt}+(1-\alpha)(\mathrm{At}-1+\mathrm{Tt}-1)$

Mevcut trend: $\mathrm{CTt}=$ At - At-1

Ortalama trend: $\mathrm{Tt}=\beta \mathrm{CTt}+(1-\beta) \mathrm{Tt}-1$

Tahmin: $\hat{\mathrm{Y}} \mathrm{t}+1=\mathrm{At}+\mathrm{T} 1$

Eşitliklerde At $\mathrm{t}$ döneminde seriye ait üssel olarak düzeltilmiş ortalamayı, CTt $t$ dönemindeki mevcut trendi, $\mathrm{Tt} \mathrm{t}$ döneminde üssel olarak düzeltilmiş trendi, $\hat{Y} \mathrm{t}+1$ gelecek dönem için tahmini, $\alpha 0$ ile 1 arasında değişen ortalamaya ait düzeltme faktörünü, $\beta 0$ ile 1 arasında değișen trend için düzeltme faktörünü ifade etmektedir.

\section{BULGULAR}

Yapılan çalışmada Çorum ilinde makarnalık buğday üreticilerinin \%46,4'ünün 61-85 yaş aralığında (ortalama 57,3) ve \%72,2'sinin ilkokul mezunu olduğu görülürken (Çizelge 5), Karabak ve Taşcı (2015), Çorum ilinde yaptıkları çalışmada buğday üreticilerinin ortalama 51,5 yaşında ve \%82'sinin ilköğretim ( 8 yıl) düzeyinde eğitim aldıklarını, Erbaş (2020), Çorum ilinde buğday üreticilerinin 52,86'sının ilkokul mezunu ve \%85.08'inin 15-64 yaş grubunda olduğunu bildirmişlerdir. Yıllar itibari ile Çorum ilinde buğday üreticilerinin eğitim ve yaş düzeylerinde değişiklik gözlenmediği, üreticilerin ortalama 50'li yaşlarda oldukları ve ilkokul düzeyinde eğitim aldıkları görülmektedir. Yaş ve eğitim düzeyi üreticilerin buğday konusunda yeni üretim teknikleri, buğday çeşitleri ve teknolojileri takip etmesi ve benimsemesi açısından önem arz etmektedir. Üreticilerin en az 3 yil en fazla 70 yıl olmak üzere ortalama 28 yıldır aralıksız makarnalık buğday üretimi yaptıkları gözlenmiştir.

Dünyada gıda güvenliği, güvenilirliği, kendine

Çizelge 5. Çorum ilinde makarnalık buğday üreticilerinin yaş ve eğitim durumu

\begin{tabular}{|c|c|c|c|c|c|c|c|c|c|c|c|c|}
\hline \multirow{2}{*}{ Tabakalar } & \multicolumn{9}{|c|}{ Eğitim } & \multicolumn{7}{c|}{ Yaş } \\
\cline { 2 - 16 } & İlkokul & Ortaokul & Lise & MYO & Lisans & Top. & -30 & $31-40$ & $41-50$ & $51-60$ & $61-85$ & Top. \\
\hline-25 & 66,7 & 0,0 & 33,3 & 0,0 & 0,0 & 100,0 & 8,3 & 8,3 & 25 & 16,7 & 41,7 & 100,0 \\
\hline $26-75$ & 71,4 & 16,7 & 7,1 & 2,4 & 2,4 & 100,0 & 4,8 & 7,1 & 14,3 & 23,8 & 50,0 & 100,0 \\
\hline $76-200$ & 71,9 & 12,5 & 9,4 & 6,3 & 0,0 & 100,0 & 3,1 & 9,4 & 15,6 & 15,6 & 56,3 & 100,0 \\
\hline $200+$ & 81,8 & 18,2 & 0,0, & 0,0, & 0,0, & 100,0 & 0,0 & 18,2 & 36,4 & 36,4 & 9,1 & 100,0 \\
\hline Ortalama & 72,2 & 13,4 & 10,3 & 3,1 & 1,0 & 100,0 & 4,1 & 9,3 & 18,6 & 21,6 & 46,4 & 100,0 \\
\hline
\end{tabular}


Çizelge 6. Çorum ilinde üreticiler tarafından bilinen makarnalık buğday çeşitleri (\%)

\begin{tabular}{|c|c|c|c|c|c|}
\hline \multirow{2}{*}{ Makarnalık buğday çeşitleri } & \multicolumn{4}{|c|}{ Tabakalar } & \multirow[t]{2}{*}{ Ortalama } \\
\hline & 1 & 2 & 3 & 4 & \\
\hline Çeşit-1252 & 75,0 & 59,5 & 43,8 & 45,5 & 54,6 \\
\hline Kiziltan 91 & 16,7 & 31 & 53,1 & 54,5 & 39,2 \\
\hline Mirzabey 2000 & 8,3 & 7,1 & 3,1 & 0,0 & 5,2 \\
\hline Kunduru 1149 & 0,0 & 2,4 & 0,0 & 0,0 & 1,0 \\
\hline Toplam & 100,0 & 100,0 & 100,0 & 100,0 & 100,0 \\
\hline
\end{tabular}

yeterlilik ve sürdürülebilirlik kavramlarının kullanımının artmasıyla, stratejik tarım ürünleri için yapılan araştırmalar da çoğalmıştır. Temel ihtiyaç maddesi olan ve Türkiye için stratejik ürünlerden biri olan buğday, ana besin kaynağ 1 olmasının yanı sıra, tarımsal ve ekonomik açıdan da önemli bir ürün olma özelliğini devam ettirmektedir (Taşcı ve ark, 2018). Türkiye'de tescilli 86 adet makarnalık buğday çeşidi olmasına rağmen (TTSM, 2020), Çorum ilinde makarnalık buğday üreticilerinin ortalama 4 adet makarnalık buğday çeşidini duyduklarını ve tanıdıkları görülürken, bu çeşitlerin TAGEM Araştırma Enstitüleri tarafından geliştirilen çeşitlerden; Kızıltan 91, Çeşit-1252, Kunduru 1149 ve Mirzabey 2000 olduğu belirlenmiştir (Çizelge 6). Bununla birlikte Çorum ilinde 2018 yılında üreticilerin \%54,6'sının Çeşit-1252 çeşidini, \%39,2'inin Kızıltan 91 çeşidini, $\% 5,2^{\prime}$ inin Mirzabey 2000 çeşidini ve \%1,0'inin ise Kunduru 1149 çeşitlerini ektiği belirlenmiştir. Ayrıca, Çeşit 1252 (Ç-1252) makarnalık buğday çeşidi yörede Çorum Ç ismiyle bilinmekte olup, üreticinin bu çeşitle ilgili olarak Çorum'a özgü geliştirilmiş bir çeşit olduğu algısı bulunmaktadır. Taner ve ark., (2015), tarımsal ürünlerin pazarlanmasında o ürüne ait çeşitlerin bilinmesinin; üretici, sanayici ve tüketici için oldukça önemli olduğunu, üreticilerin doğru bir yetiştiricilik yapabilmek amacıyla ektikleri ürünün çeşidini bilmek isteyeceklerini aynı zamanda hedef pazarlar için standart oluşturmak amaciyla pazarlamacıların da sattıkları ürünün çeşidinden emin olmak isteyeceklerini bildirmişleridir.

Çorum ilinde makarnalık buğday üreticilerinin $\% 87,6$ 'sının makarnalık buğday tohumluğu temin etmekte sıkıntı çekmediği tespit edilmiştir. Makarnalık buğday üreticilerinin tohum temin kaynakları incelendiğinde; \%34,0'ünün makarnalık buğday tohumlarını Tarım Kredi Kooperatiflerinden temin ettiği görülürken; \%19,6'sının kendi tarlasından hasat ettiği buğdayı tohumluk olarak kullandığı, \%18,6'sının tüccardan, \%13,4'ünün tohum bayilerinden, \%4,1'inin Ziraat Odasından ve \%3,1'inin TIGEM bayilerinden temin ettiği belirlenmiştir. Bütün bu değerlendirmeler ışığında, üreticilerin tohum temin fiyatları karşılaştırılmış ve en yüksek satış fiyatının Tarım Kredi Kooperatiflerine ait olduğu belirlenmiştir. (Çizelge 7).

Makarnalık buğday üreticileri içinde istedikleri makarnalık buğday tohumluğunu tedarik edemeyenüreticileriçinenönemlisorunun; yeterli 
Çizelge 7. Üreticilerin tohum temin yeri

\begin{tabular}{|l|c|c|}
\hline Tohum temin yeri & Tohum temin oranı (\%) & Tohum fiyatı (TL/kg) \\
\hline Tarım Kredi Kooperatifleri & 34,0 & 1,60 \\
\hline Kendi Tohumu & 19,6 & - \\
\hline Tüccar & 18,6 & 1,56 \\
\hline Tohum Bayisi & 13,4 & 1,58 \\
\hline Komşu Akraba & 7,2 & 1,23 \\
\hline Ziraat Odası & 4,1 & 1,51 \\
\hline TİGEM Bayi & 3,1 & 1,58 \\
\hline Toplam & 100,0 & - \\
\hline Ortalama & & 1,55 \\
\hline
\end{tabular}

tohumun bulunamaması ve istenilen çeşitlerin tohumluk fiyatlarının pahalı olması gibi faktörler olduğu görülmektedir. Üreticilerin \%30,9'unun kullandıkları makarnalık buğday tohumluğunun tamamının sertifikasız olduğu belirlenirken, \%19,6'sının tohumluğunun yarısının sertifikalı ve $\% 40,2$ 'sinin ise kullandiğ 1 tohumluğun tamamının sertifikalı olduğu belirlenmiştir (Çizelge 8). Çorum ilinde makarnalık buğday üreticilerinin sertifikalı tohum kullanım oranının düşük olduğu görülmekte olup, Bağc1 ve Y1lmaz (2016), insan ve hayvan beslenmesi için tarımda verim ve üretimin artırılmasında, en önemli teknolojik girdinin tohum olduğunu, verimde meydana gelen artışlarda sertifikalı tohumluk kullanımının etkisinin göz ardı edilemeyeceğini, sertifikalı tohumluk kullanımının daha da yaygınlaştırılması ve sertifikalı tohumluk için yeni destekleme yöntemleri geliştirilerek mevcut sertifikalı tohumluk kullanımının arttırılması gerekliliğgine vurgu yapmışlardır.

Sertifikasız tohum kullanan üreticilerin, sertifikalı tohum kullanmak için en büyük kısitlarının; istedikleri sertifikalı tohum çeşidine ulaşamamak olduğu belirlenmiştir. Nitekim Doğan ve Çetiz, (2015), makarnalık buğday üretiminde verimi kısıtlayan en önemli faktörlerin uygun çeşit ve sertifikalı tohumluk kullanılmaması olduğunu bildirerek, bu temel sorunların çözülmesi durumunda birim alandan daha fazla ürün alınarak, piyasaya daha fazla ürün arzı sağlanabileceğine dikkat çekmişlerdir. Üreticilerin kullandıkları makarnalık buğday çeşitlerini tercih etmelerinde yani çeşit seçiminde

Çizelge 8. Üreticilerin kullandıkları makarnalık buğday tohumluğunun sertifikalı olma durumu

\begin{tabular}{|c|c|c|c|c|c|c|c|c|}
\hline \multirow{2}{*}{$\begin{array}{c}\text { Tamamı } \\
\text { sertifikasız }\end{array}$} & \multicolumn{6}{|c|}{$\begin{array}{c}\text { Üreticinin kullandığı sertifikalı tohumluğunun toplam kullandı̆̆ } \\
\text { tohumluk içindeki payı (\%) }\end{array}$} & $\begin{array}{c}\text { Tamamı } \\
\text { sertifikalı }\end{array}$ & Toplam \\
\cline { 2 - 8 } & 15 & $\mathbf{5 0}$ & 60 & 80 & 90 & 93 & & \\
\hline $\mathbf{3 0 , 9}$ & 1 & $\mathbf{1 9 , 6}$ & 2,1 & 3,1 & 2,1 & 1 & $\mathbf{4 0 , 2}$ & 100,0 \\
\hline
\end{tabular}


Çizelge 9. Ekilecek makarnalık buğday çeşidinin tercihinde etkili olan kriterlerin dağılımı

\begin{tabular}{|l|c|}
\hline Kriterler & Skala \\
\hline Hastalıklara dayanıklı olması & 4,95 \\
\hline Verimin yüksek olması & 4,93 \\
\hline Kalitesi & 4,86 \\
\hline Dönme olmaması & 4,82 \\
\hline Satış fiyatı & 4,80 \\
\hline Tohum fiyatı & 4,78 \\
\hline Pazarlamasının kolay olması & 4,65 \\
\hline Kolay bulunabilir olması & 4,01 \\
\hline Alışılmış çeşit olması & 3,46 \\
\hline Tavsiye edilen çeşit olması & 3,01 \\
\hline
\end{tabular}

etkili olan kriterler Çizelge 9'da gösterilmiştir. Üreticilerin 10 başlık altında topladıkları kriterlerden ilk sirada; ekilecek makarnalık buğday çeşidinin hastalıklara dayanıklı olması, verimli ve kalitesinin yüksek olması beklentisinin olduğu görülmektedir. Kullanılacak makarnalık buğday çeşidinde dönme özelliğinin olmaması, satış fiyatının yüksek olması, tohum fiyatının uygun olmas1, pazarlamasının kolay olmas1, çeşidin kolay bulunabilir olması, alışılmış bir çeşit olması ve tavsiye edilen bir çeşit olması da üreticiler tarafindan tercih edilecek çeşitte aranılan kriterler olarak sıralanmaktadır.

Makarnalık buğday üreticilerinin \%18,6's1 kullandıkları tohumu her yıl değiştirdiğini belirtirken, \%50,5'i 2 y1lda bir, \%27,8'i 3 yılda bir ve $\% 3,1$ 'i ise 5 yılda bir değiştirdiğini belirtmiştir. Buğday ve arpa üretiminde, hem tarım işletmelerine ekonomik yük getirmemesi, hem de ülkede üretilen tohumluk miktarının tüm tohumluk ihtiyacını karşılayamayacak olması nedeniyle üreticiler için tohumluk yenileme süresinin teknik olarak 3 y1l tavsiye edildiği
(Kayaçetin, 2006) ve (TÜRKTOB, 2017) dikkate alındığında incelenen işletmelerin tohumluk yenileme sürelerinin tavsiye sürelerine uygun olduğu görülmektedir.

Araştırmanın yapıldığı 2019 yılında makarnalık buğday üreticilerine bir önceki, beş yıl önceki, on y1l önceki ve on beş yıl önceki buğday üretim sezonlarında Çorum ilinde makarnalık ve ekmeklik buğday satış fiyatları arasındaki fark sorularak bu konudaki gözlemleri istenmiştir. Çorum ilinde makarnalık buğday üretimi yapan tarım işletmecilerinin piyasa gözlemlerine göre uzun yıllar itibarıyla makarnalık buğday satış fiyatlarının ekmeklik buğdaylara göre daha yüksek olduğu görülmekte olup, bu oranın yıllar itibarıyla da arttığı belirlenmiştir (Çizelge 10). $\mathrm{Bu}$ durum, Çorum ilinde makarnalık buğday üretimini ekmeklik buğday üretimine göre daha sürdürülebilir kılmaktadır.

Çorum ilinde makarnalık buğday üreticilerinin toplam tarım arazileri, toplam buğday ekili arazileri ve toplam makarnalık buğday ekili arazilerinin yıllar itibarıyla değişimi Çizelge 
Çizelge 10. Üreticilere göre makarnalık ve ekmeklik buğday satış fiyatlarının karşılaştırması

\begin{tabular}{|l|c|c|c|c|}
\hline \multirow{2}{*}{$\begin{array}{c}\text { Üreticilere göre buğday fiyatı } \\
\text { karşılaştırması }\end{array}$} & \multicolumn{4}{|c|}{ Y1llar } \\
\cline { 2 - 5 } & 2018 & $\begin{array}{c}2017 \\
\text { (önceki y1l) }\end{array}$ & $\begin{array}{c}2013 \\
(5 \text { y1l önce) }\end{array}$ & $\begin{array}{c}2008 \\
(10 \text { y1l önce) }\end{array}$ \\
\hline Makarnalık buğday fiyatı fazla & $\mathbf{8 0 , 4}$ & $\mathbf{7 6 , 3}$ & $\mathbf{6 7 , 0}$ & $\mathbf{5 4 , 6}$ \\
\hline Ekmeklik buğday fiyatı fazla & 6,2 & 2,1 & 3,1 & 2,1 \\
\hline Fiyatı aynı & 3,1 & 2,1 & 2,1 & 1,0 \\
\hline Fikri yok & 10,3 & 19,6 & 27,8 & 42,3 \\
\hline Toplam & 100,0 & 100,0 & 100,0 & 100,0 \\
\hline
\end{tabular}

11 'de gösterilmiştir. Üreticilerin \%21,2'sinin toplam tarım arazilerinde beş y1l öncesine göre \%34,3 oranında artış, \%10,1'inin \%85,9 oranında azalış görülürken, \%68,7'sinin tarım arazi büyüklüğünde bir değişim olmadı̆̆ belirlenmiştir. Bununla birlikte üreticilerin \%20 ,2'sinin toplam buğday ekili arazilerinin \%36,2 oranında arttığ1, \%15,2'sinin \%77,7 oranında azaldığ1 ve \%64,6'sının ise buğday ekili arazi büyüklüklerinin değişmediği görülmüştür. Makarnalık buğday ekili arazilerin durumu incelendiğinde ise; üreticilerin \%15,2'sinin makarnalık buğday ekili arazileri 5 yıl öncesine göre \%53,1 oranında artarken, \%16,2'sinin makarnalık buğday ekili arazilerinin \%77,5 oranında azaldığ 1 ve \%68,7'sinin ise değişmediği belirlenmiştir. Çorum ilinde makarnalık buğday ekiliş alanlarının ekmeklik buğday ekiliş alanlarına göre azalış gösterdiği, üreticilerin makarnalık buğday ekili arazi ortalamasının 5 y1l önce 100,3 da iken 2018 y1lında \%7,2 oranında artış ile 108,1 da olduğu görülürken, ekmeklik buğday ekiliş alanları ise son 5 yılda \%11,2 oranında artış göstererek 142,3 dekardan 160,3 dekara yükseldiği belirlenmiştir. Yapılan korelasyon analizinde üreticilerin makarnalık

Çizelge 11.Tarım işletmelerinin son beş yılda tarımsal arazi miktarındaki değişim

\begin{tabular}{|c|c|c|c|c|c|c|c|c|c|c|c|c|}
\hline \multirow{2}{*}{ Değişisim } & \multicolumn{4}{|c|}{ Toplam tarım arazisi } & \multicolumn{4}{|c|}{ Toplam buğday arazisi } & \multicolumn{4}{|c|}{$\begin{array}{l}\text { Toplam makarnalık buğday } \\
\text { arazisi }\end{array}$} \\
\hline & $\begin{array}{l}5 \text { y1l } \\
\text { önce } \\
\text { (da) }\end{array}$ & $\begin{array}{l}\text { Bugün } \\
\text { (da) }\end{array}$ & $\begin{array}{c}\text { Arazide } \\
\text { değişim } \\
(\%)\end{array}$ & $\begin{array}{c}\text { Üretici } \\
\text { oranı } \\
(\%)\end{array}$ & $\begin{array}{l}5 \text { y1l } \\
\text { önce } \\
\text { (da) }\end{array}$ & $\begin{array}{l}\text { Bugün } \\
\text { (da) }\end{array}$ & $\begin{array}{c}\text { Arazide } \\
\text { değişisim } \\
(\%)\end{array}$ & $\begin{array}{c}\text { Üretici } \\
\text { oranı } \\
(\%)\end{array}$ & $\begin{array}{l}5 \text { y1l } \\
\text { önce } \\
\text { (da) }\end{array}$ & $\begin{array}{l}\text { Bugün } \\
\text { (da) }\end{array}$ & $\begin{array}{c}\text { Arazide } \\
\text { değişisim } \\
(\%)\end{array}$ & $\begin{array}{c}\text { Üretici } \\
\text { oranı } \\
(\%)\end{array}$ \\
\hline Artt1 & 222,6 & 338,7 & 34,3 & 21,2 & 226,2 & 354,9 & 36,2 & 20,2 & 102,1 & 217,9 & 53,1 & 15,2 \\
\hline Azald 1 & 243,0 & 130,7 & $-85,9$ & 10,1 & 129,0 & 72,6 & $-77,7$ & 15,2 & 122,3 & 68,9 & $-77,5$ & 16,2 \\
\hline Değişmedi & 208,9 & 208,9 & - & 68,7 & 64,0 & 64,0 & - & 64,6 & 94,7 & 94,7 & - & 68,7 \\
\hline Ortalama & 215,2 & 228,5 & 5,8 & 100,0 & 142,3 & 160,3 & 11,2 & 100,0 & 100,3 & 108,1 & 7,2 & 100,0 \\
\hline
\end{tabular}


buğday ekili arazisinin büyüklüğü ile bundan sonra makarnalık buğday üretimine devam etme fikri arasında pozitif yönlü bir ilişki olduğu belirlenmiştir $(\mathrm{p}<0.01)$. Makarnalık buğday ekili arazileri arttıkça üreticilerin makarnalık buğday üretimini sürdürme fikri de artmaktadır.

Çorum ilinde makarnalık buğday üreticilerinin gelecek yıllarda makarnalık buğday ekiliş alanları ve üretici sayılarında meydana gelebilecek değişiklikler hakkındaki görüşleri Çizelge 12'de gösterilmiştir. Üreticilerin \%36,4'ü Çorum ilinde gelecek y1llarda makarnalık buğday ekili alanların \%54,5'i ise makarnalık buğday eken üretici sayısının şimdiye göre daha da azalacağını öngörmektedir. Bu durum yıllardır makarnalık buğday üretimi ve işlenmesinde önemli bir il olan Çorum'un gelecek yıllar için bu özelliğini kaybedebileceği şeklinde yorumlanabilir.
\%47,4 azalarak 124.170 dekara düșeceği tahmin edilmektedir. 2019 yılında 60.219 ton olan üretim miktarının ise 2020 yılında \%15 azalarak 51.380 tona, 2024 yılında ise $\% 80$ azalarak 12.195 tona gerilemesi beklenmektedir.

Türkiye'de buğday üretiminin geleceği ile ilgili yapılan çalışmalarda (Kadanalı ve ark. 2019) buğday üretiminin 2019-2030 döneminde \%11,3 oranında artacağını, Özçelik ve Özer (2006). Türkiye genelinde, Akgül ve Yıldız (2016) ise Yozgat ilinde buğday üretiminin geriye doğru en fazla üç yılın buğday fiyatından etkilendiğini ortaya koymuşlardır.

Çorum ilinde bundan sonraki yıllarda makarnalık buğday üretecek tarım işletme sayısının artacağını düşünen üreticilerin (\%20 ,2) bunu destekleyen en büyük öngörüsü,

Çizelge 12. Makarnalık buğday üreticilerine göre gelecekte makarnalık buğday ekim alanı ve üretici sayısının durumu (\%)

\begin{tabular}{|l|c|c|}
\hline & Makarnalık buğday ekili alanlar & Makarnalık buğday eken üretici sayıs1 \\
\hline Azalır & 36,4 & 54,5 \\
\hline Artar & 19,2 & 20,2 \\
\hline Değişmez & 38,4 & 22,2 \\
\hline Fikri yok & 6,1 & 3,0 \\
\hline Toplam & 100,0 & 100,0 \\
\hline
\end{tabular}

Yapılan beş yıllık gelecek tahminleri de üreticilerin Çorum ilinde makarnalık buğday ile ilgili öngörülerini doğrular niteliktedir. Tahminlerde Çorum ilinde makarnalık buğday ekim alanlarının ve üretim miktarının kademeli olarak azalması beklenmektedir. 2019 yılında 236.744 dekar olan Çorum ili makarnalık buğday ekim alanının 2020 yılında \% 9,3 azalarak 241.220 dekara, 5 y1lın sonunda 2024 yılında ise makarnalık buğday satış fiyatlarının yüksek oluşu ve makarnalık buğdayın yöreye uygun ve dayanıklı bir bitki olması, veriminin yüksek oluşu, satış kolaylığının olmasının da etkisiyle makarnalık buğday üretici sayısının gelecek y1llarda artacağı şeklindedir. Çorum ilinde bundan sonraki yıllarda makarnalık buğday üretecek tarım işletme sayısının azalacağını düşünen üreticilerin $(\% 54,5)$ büyük çoğunluğu, 
Çizelge 13. Çorum ili beş yıllık makarnalık buğday ekim alanı ve üretim miktarı tahmini

\begin{tabular}{|l|c|c|}
\hline Y1llar & Ekim alanı (da) & Üretim (ton) \\
\hline 2019 & 236.744 & 60.219 \\
\hline 2020 & 214.220 & 51.380 \\
\hline 2021 & 191.708 & 41.583 \\
\hline 2022 & 169.195 & 31.787 \\
\hline 2023 & 146.683 & 21.991 \\
\hline 2024 & 124.170 & 12.195 \\
\hline
\end{tabular}

kırsal alandan kente göç sonucunda tarımdan kopuşun etkisi, makarnalık buğday üretim maliyetlerinin çok yüksek, ürün satış fiyatlarının düşük olması, alternatif ürünlere yöneliş ve makarnalık buğdayın veriminin düşük olması gibi faktörler sebebiyle üreticilerin makarnalık buğday üretiminden vazgeçeceği görüşünde birleşmişlerdir.

Makarnalık buğday gibi tek y1llık bitkilerde üreticilerin çeşit tercihleri, üretim sezonunda hasat ettiği çeşitten memnuniyetine göre bir sonraki üretim sezonunun çeşit kararına etkili olmaktadır. Memnuniyet kriterleri sadece verim ve satış fiyatı ile kısıtlı olmayıp, çeşidin tohumuna ulaşılabilmesi, tohum fiyatının uygunluğu, çeşidin bölgenin toprak, iklim ve ekolojisine uygun olması, soğuğa, kuraklığa, hastalık ve zararlılara dayanıklı olması, kalitesi ve pazarlama durumu gibi kriterler de etkili olup, bunların yanında bir diğer önemli kriter de üretici alışkanlıklarıdır. Çorumilinde makarnalık buğday üreticilerinin \%35,0'inin daha önce kullanıp memnun kalmadığı ve bir daha kullanmayı düşünmediği en az bir makarnalık buğday çeşidinin olduğu belirlenmiş olup, Çizelge 14'te makarnalık buğday üreticilerinin daha önce kullanıp memnun kalmadığı ve kullanımından vazgeçtiği makarnalık buğday çeşitleri gösterilmiştir. Kunduru 1149 çeşidi Çorum ilinde üreticilerin en fazla vazgeçtiği çeşit olarak öne çıkarken, Çeşit-1252 ve Kızıltan 91 çeşitleri de vazgeçilen çeşitler arasında yer almaktadır. Her bir makarnalık buğday üreticisinin, ekimini yaptığı makarnalık buğday çeşidinden bireysel beklentisi farklı olabilmektedir. $\mathrm{Bu}$ bağlamda, üreticilerin daha çok, makarnalık buğday çeşitlerinin verimlerinden memnun kalmadıkları için vazgeçtiği göze çarparken; dönme özelliği, kurağa, soğuğa, yatmaya ve hastalıklara karşı dayanıksız olmaları, tohumluğunun bulunamaması ve pazarının olmaması

Çizelge 14. Üreticilerin vazgeçtiği makarnalık buğday çeşitleri

\begin{tabular}{|l|c|}
\hline Vazgeçilen makarnalık buğday çeşitleri & $\%$ \\
\hline Kunduru 1149 & 73,4 \\
\hline Çeşit-1252 & 18,8 \\
\hline Kızıltan 91 & 7,8 \\
\hline Toplam & 100,0 \\
\hline
\end{tabular}




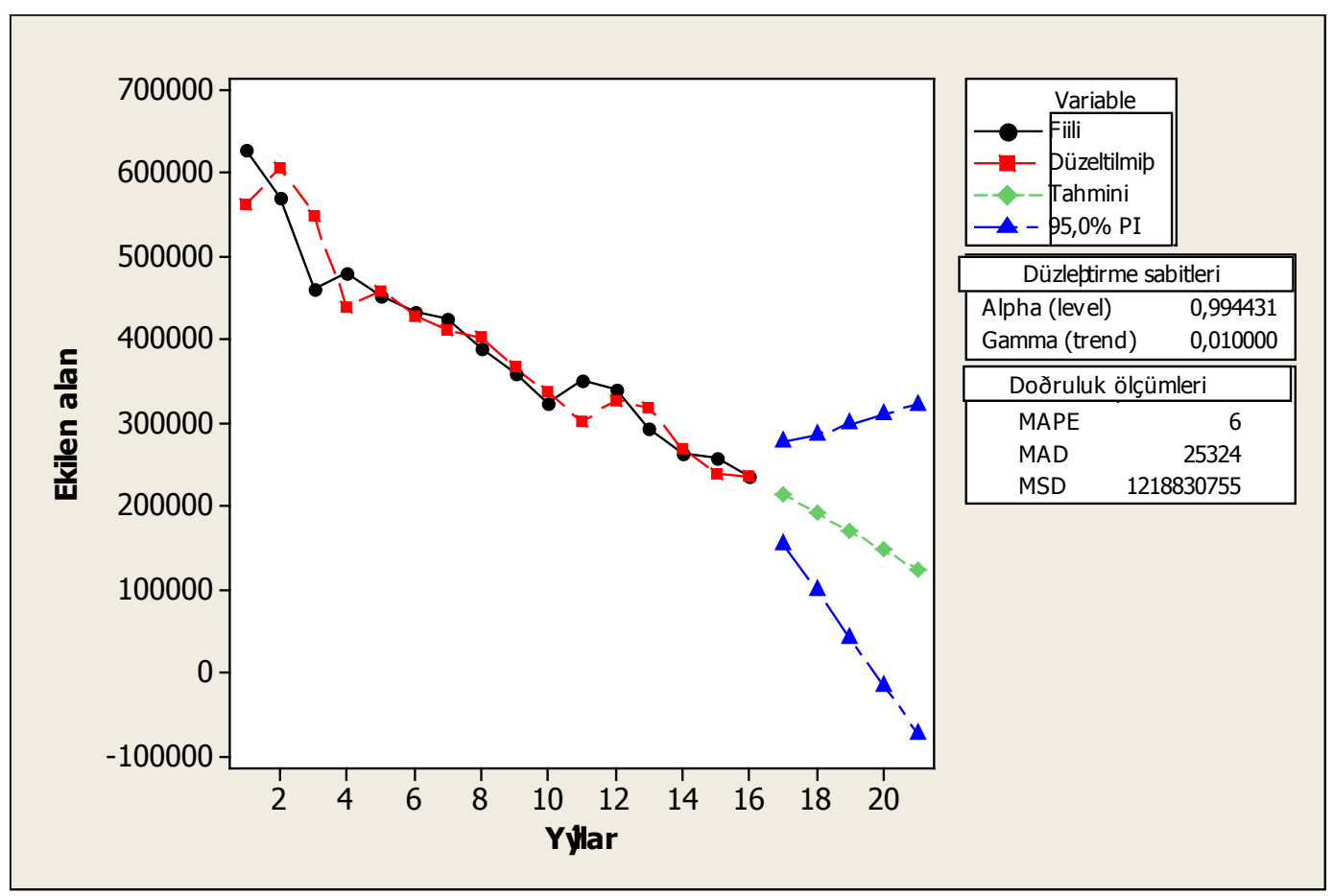

Şekil 2. 2020-2024 yıllarına ait Çorum ili kuru fasulye ekim alanlarının tahmini ve sınır değerleri

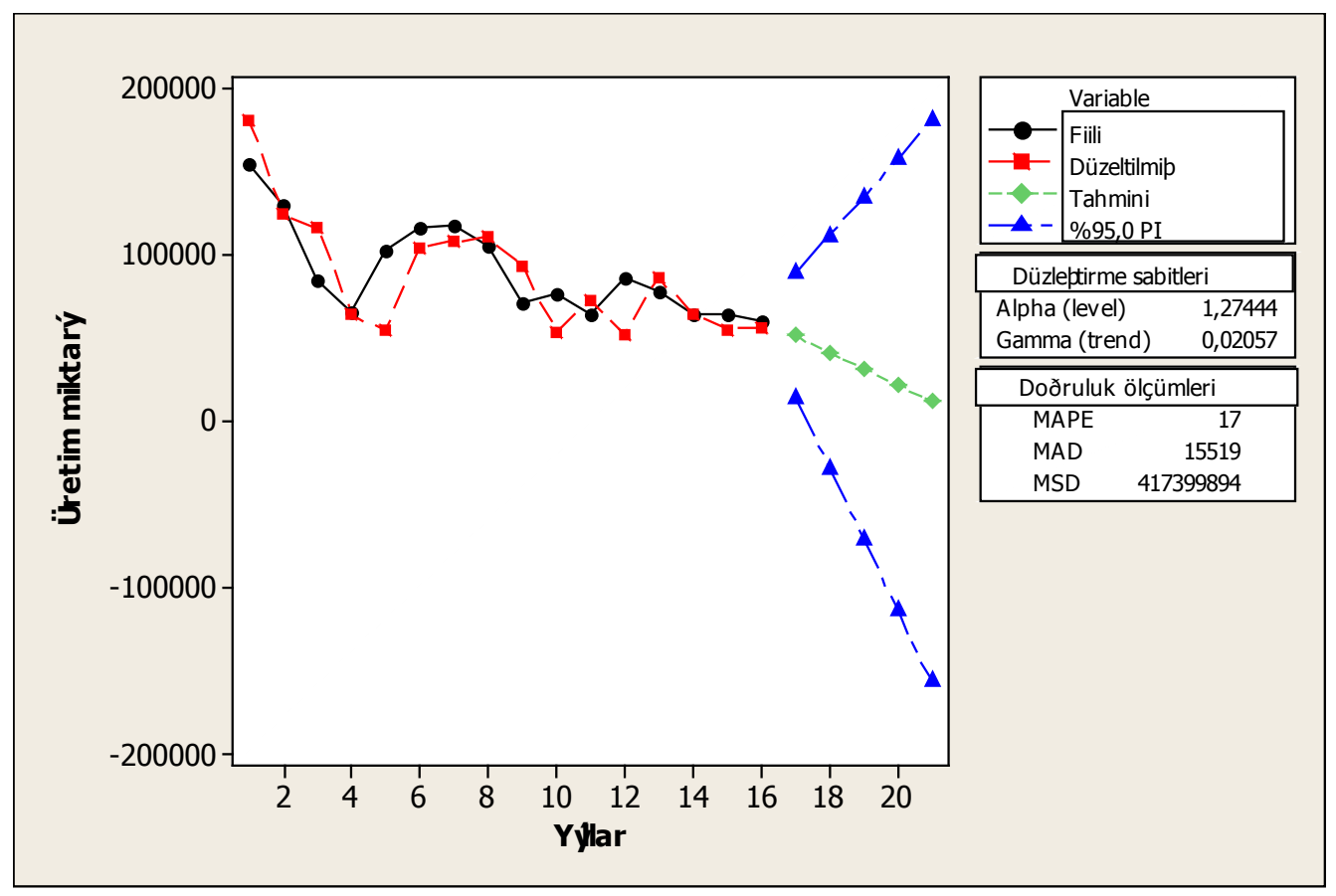

Şekil 3. 2020-2024 yıllarına ait Çorum ili kuru fasulye üretim miktarının tahmini ve sınır değerleri 
gibi nedenlerle de çeșitlerden vazgeçildiği görülmektedir.

\section{Üreticilerin kullanımından vazgeçtikleri} makarnalık buğday çeşitleri olduğu gibi, uzun yıllardır memnun kalarak ekimine devam ettiği veya yakın zamanda ekimine başlayıp memnun kaldığı makarnalık buğday çeşitlerine bağlılıkları da gözlenmiştir. Tek yıllık bitkilerde memnuniyet durumuna göre çeşitten vazgeçmek ve yeni bir çeşide geçiş kolay olmaktadır. Üretici alışkanlıkları ve davranışı itibarıyla çeşit değiştirmek yeni bir riski göze almayı da beraberinde getireceği için üreticilerin beklentilerini karşılayan çeşitlerden vazgeçmedikleri görülmüştür. Çorum ilinde üreticilerin \%31,3'ünün vazgeçemeyeceği bir makarnalık buğday çeşidi olduğu belirlenmiştir. Kızıltan 91 ve Çeșit-1252 çeșitleri; verim, bölgeye uygunluk, hastalık ve soğuğa dayanıklılık, renk ve kalite özellikleri, üretici alıskanlıkları, pazarlaması ve yörede iyi fiyata satılma olanaklarına sahip bir makarnalık buğday çeşidi olmasına bağlı olarak üreticilerin büyük çoğunluğu tarafindan vazgeçilmeyecek çeşitler arasında gösterilmekle birlikte bu çeşitlerden daha iyi özelliklere sahip makarnalık buğday çeşitlerinin bölgede kullanılmaya başlamasına bağl1 olarak bu cesitlerden de vazgeçilebileceği Cizelge 15. Ureticilerin ekiminden vazzgeçmeyi belirlenmiştir (Çizelge 15).

Çorum ilinde makarnalık buğday üreticilerinin $\% 90,1$ 'inin bundan sonraki yıllarda da makarnalık buğday üretimine devam etmeyi düşündüğü belirlenmiştir. Üreticilerin makarnalık buğday üretimini sürdürme düşüncelerinin sebeplerinin başında makarnalık buğdayların yöreye uygun ve dayanıklı bir bitki olması gelmekte, bunun yanında makarnalık buğdaydan başka ekilecek alternatif bir bitki olmaması da makarnalık buğday üretimine devam etmeleri açısından bir diğer sebep olarak görülmektedir. Üretici alışkanlı̆̆ı, iyi verim alınması ve kolay pazarlama imkanlarının olması gibi faktörler de makarnalık buğday üretiminin sürdürülmesi için önemli sebepler olarak belirlenmiştir. Makarnalık buğday üreticileri içinde gelecek yıllarda bitkisel üretim deseni içinde makarnalık buğdaya yer vermeyecek üreticileri, makarnalık buğday üretiminden uzaklaşma düşüncesine sevk eden en önemli faktör; tarımsal üretim girdilerinin pahalı olmasına bağlı olarak maliyetlerin artması ve ürün satış fiyatlarının düşük olması ile yaşlı üreticilerin üretimden çekilecek olmalarına bağlanmaktadır. Verimlerin düşük olması, maliyetlerin artması ve satış fiyatının düşük olması karşısında üreticilerin makarnalık buğday üretimini sürdürebilmesi icin birim alandan daha medikleri makarnalık buğday çeşitleri

\begin{tabular}{|l|c|}
\hline \multicolumn{1}{|c|}{ Makarnalık buğday çeşidi } & $\%$ \\
\hline Kızıltan 91 & 45,3 \\
\hline Çeşit-1252 & 38,7 \\
\hline Kunduru 1149 & 9,6 \\
\hline Mirzabey 2000 & 6,4 \\
\hline Toplam & 100,0 \\
\hline
\end{tabular}


Çizelge 16. Makarnalık buğday üretimini birinci öncelikli sınırlandıran faktörler

\begin{tabular}{|l|c|}
\hline \multicolumn{1}{|c|}{ Üretimi sınırlandıran faktörler } & $\%$ \\
\hline Mazot satış fiyatlarının yüksek olması & 31,3 \\
\hline Makarnalık buğdayda dönme sorunu & 19,2 \\
\hline Gübre satış fiyatlarının yüksek olması & 14,1 \\
\hline Ürün satış fiyatlarının düşüklüğü & 10,1 \\
\hline Pazarlama sorunu & 8,1 \\
\hline Tohumluk fiyatlarının yüksekliği & 5,1 \\
\hline Tarımsal ilaç fiyatlarının yüksekliği & 3,0 \\
\hline Su kısıtı & 3,0 \\
\hline Verim düşüklüğü & 3,0 \\
\hline Kuraklığın etkisi & 3,0 \\
\hline Toplam & 100,0 \\
\hline
\end{tabular}

Çizelge 17. Üreticilerin çok sayıda makarnalık buğday çeşidinin mevcut olması hakkında düşünceleri

Çok çeşit olması hakkında üretici düşünceleri

Alternatif iyidir çok çeşit olmalıdır

\begin{tabular}{|l|c|}
\hline Fikri yok & 31,3 \\
\hline Çok sayıda çeşit olması üretici açısından iyi değildir & 12,1 \\
\hline Toplam & 100,0 \\
\hline
\end{tabular}

fazla verim alması gerekliliği sonucunda, istediği verimi de elde edemeyen üreticilerin makarnalık buğday üretiminden vazgeçme noktasına geldiği görülmektedir. Üreticiler açısından makarnalık buğday üretimini sınırlandıran en önemli faktörlerin başında tarımsal girdi fiyatlarının pahalı olması gelmektedir. Nitekim araştırma alanında üreticilerin makarnalık buğday üretimini sinırlandıran birincil faktörlerin içinde $\% 31,3$ oranıyla mazot fiyatlarının artışı ve \%19,2 oranıyla dönme sorununun öne çıktığı görülmektedir (Çizelge 16). Gübre satış fiyatlarının yüksek olması, ürün satış fiyatlarının düşük olması, pazarlama sıkıntısı, tohumluk fiyatlarının yüksekliği, zirai ilaç fiyatlarının yüksekliği, su kısıtı ve verim düşüklüğü gibi etmenler; makarnalık buğday üretimi yapan tarım işletmelerini kısıtlayan diğer faktörler olarak sıralanmıştır. Aalami ve ark., (2007), makarnalık buğdayın kalitesinin iklim özelliklerinden etkilendiğini, başaklanma ve çiçeklenme dönemlerinde gelen yağışların 'dönmeyi' artırdığını, bu durumunda makarnalık buğdayın kalitesini düşürdüğünü ve satış fiyatını azalttığını bildirmişlerdir.

Buğday 1slah çalışmaları, buğday üretiminde verimi ve kaliteyi artırmayı ve bunları sınırlayan kuraklık, soğuk-sıcak stresi, kışa dayanıklılık, yatma, mikro element noksanlığı, yetiştirme teknikleri, hastalık ve zararlılar gibi etmenlere karşı dayanıklı çeşitler geliştirmeyi 
hedeflemektedir. Türkiye'de ekoloji ve iklim şartlarına uyumlu olarak tavsiye edilen tescilli 86 adet makarnalık buğday çeşidi mevcut olup (TTSM, 2020), bu konuda Çorum ilinde makarnalık buğday üreticilerinin düşünceleri Çizelge 17'de gösterilmiştir. Üreticilerin \%56,6 gibi büyük bir oranı çok sayıda makarnalık buğday çeşidinin üreticiler için tercihte bir alternatif oluşturduğunu ve çok çeşit olmasını olmasından daha fazla önemli olduğunu ve çeşitlerin birbirine benzer özellik taşıdığını ve birbirinde farklarının olmadığını belirtmişlerdir.

Buğday gibi, insanın her gün sabahtan akşama kadar çok farklı şekillerde yararlandığı temel bir ürün için, sslah çalışmaları ve geliştirilen modern çeşitler önemlidir. Türkiye'de buğday ıslah çalışmaları üretimde verimi ve kaliteyi artırmak

Çizelge 18. Üreticilerin makarnalık buğday satışında fiyata etki ettiğini düşündüğü kriterler
Kriterler
Skor
Standart Sapma

\begin{tabular}{|c|c|c|}
\hline Camsilık & 4,92 & 0,42 \\
\hline İrmik rengi & 4,91 & 0,41 \\
\hline Gluten & 4,89 & 0,74 \\
\hline Yabancı maddenin az olması & 4,86 & 0,57 \\
\hline Protein oran1 & 4,78 & 0,98 \\
\hline Hektolitre & 4,73 & 0,78 \\
\hline Rutubet & 4,59 & 0,78 \\
\hline Satış tarihi & 3,97 & 1,35 \\
\hline Çesit & 3,55 & 1,44 \\
\hline Yöre & 3,17 & 1,39 \\
\hline $\begin{array}{l}\text { Skor dereceleril: çok önemsiz 2: önemsiz 3: normal 4: önemli 5: çok } \\
\text { önemli }\end{array}$ & & \\
\hline
\end{tabular}

olumlu bulduklarını bildirirken; üreticilerin \%31,1'inin makarnalık buğday çeşitlerinin çok olması hakkında bir fikirlerinin olmadığını, $\% 12,1$ 'i ise çok fazla çeşit olmasının iyi bir şey olmadığını, kendi yörelerinin iklim ve toprak şartlarına uygun verimli çeşitlerin kendi bölgelerinde pazarlanmasını çok fazla çeşit

ve bunları sınırlayan kuraklık, soğuk-sıcak stresi, kışa dayanıklılık, yatma, mikro element noksanlığı, yetiştirme teknikleri, hastalık ve zararlılar gibi etmenlere karşı dayanıklı çeşitler geliştirmek amacıyla Cumhuriyetin ilanından hemen sonra başlamıştır. Günümüzde de buğdaya

Çizelge 19. Çorum ilinde buğday üretim maliyeti ve satış fiyatlarının karşılaştırılması (TL/kg) Buğday üretim maliyeti TMO’ya satış fiyatı

Tüccara satış fiyatı

\begin{tabular}{|c|c|c|}
0,60 & 1,02 & 0,93 \\
\hline Fark & 0,42 & 0,33 \\
\hline
\end{tabular}


yönelik Ar-Ge faaliyetleri, ıslah çalışmaları ve üretim teknolojileri geliştirmeleri hem kamu hem de özel sektör tarafindan durmaksızın devam ettirilmektedir (Anonim, 2016/b). Buğdayda Ar-Ge ve inovasyon çalışmalarının nihai kullanıcısı olan üreticilerin, bu çıktıları takip etmesi ve kullanıcısı olması ise beklenen bir durumdur. Çorum ilinde makarnalık buğday üreticilerinin \%60,0'^nın yeni geliştirilen makarnalık buğday çeşitlerini takip etmediği ve yeni geliştirilen çeşitler ile ilgilenmediği görülmektedir. $\mathrm{Bu}$ durum hem kamu hem de özel sektör 1slah kuruluşları ve yayımcıları için üzerinde durulması gereken önemli bir husus olarak dikkat çekmektedir. Üreticilerin yeni geliştirilecek makarnalık buğday çeşitlerinde öne çıkmasını istediği ve olmazsa olmaz dediği en önemli özelliğin “verim” olduğu belirlenmiştir. Yeni çeşitlerde verimli olma özelliğinin mutlaka olması gerektiğini, bekledikleri diğer özelliklerin verimin yanında sağlanabilirse anlamı olduğunu belirtmişlerdir. Ekim alanlarının kullanılabilecek sinırlara gelmesi, artan girdi maliyetleri ve ürün satış fiyatlarının düşüklüğünün sonucu olarak üreticiler birim alandan en fazla miktarda verim alarak üretimlerini sürdürebilecekleri makarnalık buğday çeşitlerini kullanmak istemektedirler.

Üreticilerin, hasattan sonra makarnalık buğdaylarının satışında makarnalık buğdayın alım fiyatına etki ettiğini düşündüğü kriterler Çizelge 18'de gösterilmiştir. 5'li likert ölçeğine göre yapılan skorlama sonucunda Çorum ilinde; üreticilerin satılacak makarnalık buğdaylarda camsılık oranının yüksek oluşu, irmik rengi, gluten kalitesi, temiz olması yani diğer bitki tohumları ile karışık olmaması, protein, hektolitre ve rutubet oranının fiyatlandırmaya önemli etki ettiğini düşündükleri belirlenmiştir. Aydoğan ve ark. (2012), makarna sanayi açısından en önemli sorunun, makarna yapımına uygun, yüksek kalitede buğday bulunmaması olarak bildirmişler ve kaliteye önem veren makarna sanayicilerinin; protein miktarı yüksek, protein kalitesi iyi, renk bakımından yeterli ve pişme kalitesi uygun çeşitler istediklerine vurgu yapmışlardır. Cubadda ve ark., (2007), makarnalık buğdayın hammadde olarak kullanıldığı sektörün isteklerine göre 1slah kuruluşlarının yeni makarnalık buğday çeşitleri geliştirdiklerini. makarna kalitesinde renk ve pişme özellikleri öne çıkan özellikler olup, doğrudan makarnalık buğdayın irmik kalitesinden etkilendiğini belirterek, makarnalık buğdayın protein oranı ve kalitesi makarnanın pişme kalitesinde önemli rol oynadığına vurgu yapmışlar ayrıca buğdaylarda unun gluten kuvvetinin yüksek olması, pişmesi sırasında organik maddelerin suya karışma oranını azalttığı, makarna üreticilerinin iyi bir son ürün elde etmek için güçlü gluten ve yüksek protein içeriğine sahip irmik talep ettiklerini bildirmişlerdir.

Çorum ilinde makarnalık buğday üreticilerinin, elde ettikleri makarnalık buğdayları hasat sonrasi; tüccar ve TMO'ya sattığ1 ve en yüksek alış fiyatının TMO tarafından verildiği görülmektedir

Yalvaç ve ark (2010), makarnalık buğday üretiminde yaşanan başlıca sorunları, verim düşüklüğü, düşük adaptasyon kabiliyeti, hastalıklara duyarlılık, özellikle uygun yetiştirme tekniklerinin yeterince yaygınlaşmamış olmasından kaynaklanan kalite düşüklüğü ve 
genetik potansiyeli yüksek çeşitlere ait sertifikalı tohumlukların yeteri miktarda üretilemeyişi ve bunların çiftçiler tarafından yaygın ve sık şekilde kullanılmayışı olarak belirlemişlerdir. Makarnalık buğdaylar, ekmeklik buğdaylara göre üretim riskinin yanında pazarlama riskini de barındırmaktadır. Ekmeklik buğdayların ekiliş ve kullanım alanlarının genişliğine oranla alıcı yelpazesi de ülke geneline dağılımı homojen bir yapıdayken, makarnalık buğdayı hammadde olarak kullanan tarıma dayalı sanayi kuruluşları ülkenin belli yörelerinde toplanmıştır. $\mathrm{Bu}$ kümelenme genellikle Güneydoğu Anadolu ve İç Anadolu Bölgesinde oluşmuştur. Bundan dolayı makarnalık buğdayları hammadde olarak kullanan makarna ve bulgur fabrikalarının Çorum ilinde faaliyet göstermesi; Çorum ilinde makarnalık buğday üretiminin sürdürülebilmesi açısından önemli bir faktördür. Çorum ilinde üreticilerin büyük bir bölümünün makarnalık buğdaylarını tüccara sattıkları ve tüccarların büyük bir çoğunluğunun ürünlerinin makarnalık buğday alım kriterlerinin çok altında aldıkları belirlenmiştir. TMO'nun alım ofislerinin olmadığ 1 bölgelerde, tüccarların da kalite kriterlerine göre alım yapmaması ve makarnalık buğdayda dönme riskinin bulunması üreticiler için makarnalık buğdayı beklediği fiyatın çok altında satmasına zemin hazırlamaktadır. Hasat zamanı ile TMO alım merkezlerinin alım yaptığı tarihlerin uyuşmadığı bölgelerde üretici yöreye göre birkaç tüccarın belirlediği fiyattan makarnalık buğdaylarını pazarlamak zorunda kalmaktadır. Makarnalık buğdayı hammadde olarak kullanan sanayinin ülkenin belli bölgelerinde faaliyet göstermesine bağlı olarak bu bölgelere uzak yörelerde makarnalık buğday üretimi yapan üreticilerin ürünlerini pazarlamasında bazı kısıtlar oluşmaktadır. Tüccardan istediği fiyatı alamamalarına rağmen üreticiler, nakliye masraflarını göze alamadığı için ve başka pazarlama imkânı da kalmadığından tüccarların belirlediği alım fiyatlarına mecbur kalmaktadır. $\mathrm{Bu}$ durumda kalite kriterlerinin ve makarnalık buğday üretim zorluğunun fiyata yansımadığını gören üreticiler bir sonraki üretim sezonunda ya yüksek verimli makarnalık çeşitlere yönelerek kaliteyi ikinci plana atmakta veya makarnalık buğday üretiminden vazgeçerek alternatif bitkilere geçiş yapmaktadır. Makarnalık buğday üretiminin sürdürülebilmesi için, Çorum ilinde üreticilerin \%81,8'i makarnalık buğday üretimine ayrı bir tarımsal destekleme verilmesini talep etmektedir.

\section{SONUÇ VE ÖNERÍLER}

Çorum ili makarnalık buğday ekiliş alanı, üretimi ve tarıma dayalı sanayisi bakımından uzun yıllardır Türkiye'nin Orta Anadolu Bölgesinde önemli üretim bölgelerinden birisi durumundadır. Çorum ilinde makarnalık buğday üretimi yıldan yıla azalma gösterse de, tarım işletmelerinin gelecek yıllarda da üretimlerini sürdürme kararlılığı içinde olduğu belirlenirken, üreticilerin büyük bir bölümünün, tescil tarihleri çok eski olan makarnalık buğday çeşitlerini kullandığı görülmektedir. Bunun için makarnalık buğday konusunda yayım eksikliğinin giderilmesi, yeni geliştirilen makarnalık buğday çeşitlerinin ve üretim tekniklerinin üreticiye ulaştırılma çalışmalarının artarak sürdürülmesi gereklidir. Makarna ve bulgur fabrikalarının faaliyet gösterdiği Çorum ilinde üreticilerin 
makarnalık buğdayı pazarlama konusunda karşılaştığ 1 problemlerin çözülmesi, makarnalık buğday üretiminin sürdürülebilmesi için önem taşımaktadır. Tarım sektörünün yapısı, tarımın mevsimsel özellikleri ve işletmelerin ekonomik durumlarından dolayı üreticilerin hasatla birlikte en geç iki üç ay gibi kısa sürede ürünlerini pazarlayarak paraya dönüştürme ihtiyaçları bulunduğundan; TMO'nun borsa ve lisanslı depolarda buğday alımını yaygınlaştırması da fiyat oluşumunda ve üreticinin pazarlama problemlerinin çözümünde önemli bir rol oynamaktadır. Makarnalık buğdayların ekmeklik buğdaylar ile rekabet edebilmesi için son y1llara kadar verim birinci öncelik olurken, özellikle makarna ve bulgur sanayisinin gelişmesi ile verimden daha çok kalitenin ön plana çıktığ 1 görülmektedir. Sanayici özellikle iç ve diş piyasada rekabet edebilmek için renk ve protein kalitesi yüksek çeşitleri tercih etmekte olup, buna bağlı olarak makarnalık buğday 1slah programlarının planlanmasında ve yürütülmesinde çeşit geliştiren kurum/ kuruluşlar ile tarıma dayalı sanayicilerin ve üreticilerin de ihtiyacına yönelik yeni çeşit geliştirme işbirliklerinin arttırılması gereklidir. Çorum ilinde olduğu gibi Türkiye genelinde de gelecek yıllarda makarnalık buğday ekim alanlarında ve üretim miktarında azalmanın olabileceği de göz önünde bulundurularak, makarnalık buğdayların mevcut üretim bölgeleri olan, iklim ve toprak yapısının yanında bu konuda üretici alışkanlıkları da bulunan, özellikle Güneydoğu Anadolu ve Orta Anadolu Bölgelerinde özel makarnalık buğday üretim alanları belirlenerek, bu alanlarda makarnalık buğday üretimine özel ayrı bir tarımsal destekleme sistemi önerilebilir.

\section{AÇIKLAMA}

Bu makalede 2019 yılı Nisan ayına ait araştırma verileri kullanılmış olup, çalışmanın yürütülmesi ve sonuçların yazılması esnasında araştırma ve yayın etiğine uyulmuştur. Herhangi bir "Çıkar Çatışması" bulunmamaktadır.

Araştırmada "Katkı Oranına" göre yazar sıralamasına uyulmuştur.

\section{TEŞEKKÜR}

$\mathrm{Bu}$ çalışmada; Tarım ve Orman Bakanlığı, Tarımsal Araştırmalar ve Politikalar Genel Müdürlüğü tarafından desteklenen TAGEM/ TEPAD/Ü/18/A8/P1/1417 numaralı “Türkiye'de Makarna Sektörünün Rekabet Analizi" isimli projeden elde edilen verilerden yararlanılmıştır.

\section{KAYNAKÇA}

Aalami M. Leelavathi K. Rao U.J.S.P., 2007. Spaghetti making potential of Indian durum wheat varieties in relation to their protein, yellow pigment and enzyme contents. Food Chemistry, 100, 1243- 1248.

Akgül S. Y1ldız Ş. 2016. Yozgat'ta Buğday Üretimi ve Fiyat İlişkisinin Koyck Modeliyle Analizi. Uluslarası Bozok Sempozyumu 2016: 5-7.

Anonim, 2016/a. Bazı Tarım ve Gıda Ürünlerinin Piyasa Değişkenlerine Yönelik Öngörüler, Gıda, Tarım ve Hayvancılık Bakanlığı Tarımsal Araştırmalar ve Politikalar Genel Müdürlüğü Yayını.

Anonim, 2016/b, Türkiye'nin buğday atlas1, WWF Doğal Hayatı Koruma Vakfi-Türkiye ISBN: 978-605-9903-07-3- İstanbul. 
Aydoğan S. Şahin M. Akçacık A.G. Kaya Y. Kara İ. Türköz M. Akçura M. 2012. Bazı makarnalık buğday çeşitlerinin kalite özelliklerinin belirlenmesi. International Journal of Agricultural and Natural Sciences, 5(1), 82-85.

Bağcı S. A. Y1lmaz K. 2016. Türkiye tohumculuk sektöründeki gelişmeler ile bu gelişmelerin sertifikalı tohumluk kullanımına ve verim üzerine muhtemel etkileri. Tarla Bitkileri Merkez Araştırma Enstitüsü Dergisi, 25 (özel say1-1), 299-303.

Bayaner A. Yağlı T. Özkan H. 2010. Makarnalık buğday pazarlaması ve sorunları. Makarnalık buğday mamulleri Konferans Bildiri Kitabı. 17-18 Mayıs 2010 Şanlıurfa. Bushuk W, 1998. Wheat breeding for endproduct use. Euphytica, 100, 137-145.

Cubadda, R. E., Carcea, M., Marconi, E., Trivisonno, M.C.2007. Influence of protein content on durum wheat gluten strength determined by the SDS sedimentation test and by other methods. Cereal Foods World 52: 273-277.

Demirbaş N. Atış E. 2005. Türkiye tarımında g1da güvencesi sorununun buğday örneğinde irdelenmesi. Ege Üniversitesi Ziraat Fakültesi Dergisi, 42(1), 179-190.

Doğan Y. Cetiz M. 2015. Türkiye'de tescil edilmiş bazı makarnalık buğday (Triticum Durum L.) çeşitlerinin Mardin-Kızıltepe koşullarında verim ve kalite özelliklerinin belirlenmesi. Yüzüncü Y1l Üniversitesi Tarım Bilimleri Dergisi, 25(3), 304-311.

Elgün A, Ertugay Z. 1995. Tahıl işleme teknolojisi. Atatürk Üniversitesi Ziraat Fakültesi, Erzurum.
Erbaş N. 2020. Çorum ili tarım işletmelerinde kışlık buğday (Triticum aestivum L.) üretiminin maliyet analizi. Iğdır Üniversitesi Fen Bilimleri Enstitüsü Dergisi, 10(2), 1318-1328.

FAO, 2020. FAO Birleşmiş Milletler Gıda ve Tarım Örgütü FAOSTAT. Erişim: http:// www.fao.org/faostat/en/\#data [Erişim tarihi 07.05.2020].

Hoseney RC. 1994. Principles of cereal science and technology (2nd ed.). American Association of Cereal Chemists, St. Paul, $\mathrm{MN}$

Kadanalı, E., Yazgan, Ş., Yalçınkaya, Ö., (2019). Arima Model for Forecasting Wheat Production in Turkey . 4th INTERNATIONAL CONFERENCE ON ADVANCES IN NATURAL APPLIED SCIENCES-ICANAS 2019 (pp.773-780). Ağrı, Turkey

Karabak S. Taşcı R. 2015. Sivas ve Çorum illerinde buğday üretiminde teknoloji kullanım düzeyi, GAP VII.Tarım Kongresi 28 Nisan-1 Mayıs 2015 HRÜ Şanlıurfa, ISBN:978-975-7113-45-4 Sayfa:193-199., Cilt 1.

Kayaçetin F. 2006. Buğday (triticum aestivum 1.) ve arpa (hordeum vulgare 1.)'da tohumluk üretimi, Tarla Bitkileri Merkez Araştırma Enstitüsü Dergisi, 15 (1-2).

Kılıç Yolal A. Değirmenci H. 2020. Basınçlı sulama sistemleri hibe destek uygulamalarının değerlendirilmesi. Çorum ili örneği, KSÜ Tarım ve Doğa Derg 23 (5): 1175-1183. DOI: 10.18016/ksutarimdoga. vi.656052

Kınacı E. 1993. Cumhuriyetten bugüne 
makarnalık buğday araştırmalara ve gelişmeler. Makarnalık Buğday ve Mamulleri Sempozyumu. Sayfa:49-55. Ankara

Kün E. 1988. Serin iklim tahılları. A.Ü. Ziraat Fakültesi Yayınları. No:1032 Ders Kitabı, 299, s. 322, Ankara

Özçelik, A. Özer, O.O 2006. Koyck Modeliyle Türkiye'de Buğday Üretimi ve Fiyatı İlişkisinin Analizi. Tarım Bilimleri Dergisi 12(4), 333-339.

Savc1 S. Turan F. 2016. Kırsal alanda çiftçilerin pestisit kullanımının incelenmesine yönelik anket çalışması: Çorum Külhüyük Köyü örneği. Land Use Policy, 26(4), 961974.

Süzer S. 2012. Buğday tarımında verim ve kalitenin arttırılması için uygun yetiştirme tekniklerinin önemi. Türkiye Tohumcular Birliği Dergisi (4) s 58-63

Taner A. Tekgüler A. Sauk H. 2015. Yapay sinir ağları ile makarnalık buğday çeşitlerinin sınıflandırılması, Anadolu Tarım Bilimleri Dergisi, (30), 51-59.

Taşcı R. Karabak S. Bolat M. Pehlivan A. Şanal T. Acar O. Külen S. Güneş E. Albayrak M. (2018). Ankara ilinde un fabrikalarının buğday alım kriterleri, üretim ve pazarlama yapıları. Tarla Bitkileri Merkez Araştırma Enstitüsü Dergisi, 27 (2), 82-91. DOI: 10.21566/tarbitderg.501479

TTSM, 2020. Tohumluk Tescil ve Sertifikasyon Merkez Müdürlüğü Erişim: https://www. tarimorman.gov.tr/BUGEM/TTSM/ Sayfalar/Detay.aspx?SayfaId=85 [Erişim tarihi 08.06.2020].

TÜİK, 2020. Türkiye İstatistik Kurumu Erişim:
http://www.tuik.gov.tr/PreÇizelge.do?alt_ $\mathrm{id}=1001$ [Erişim tarihi 07.05.2020].

TÜRKTOB， 2017. Ülkemizde tohumluk pazarlaması, karşılaşılan sorunlar ve çözüm önerileri, TÜRKTOB resmi internet sayfası https://www.turktob.org.tr/dergi/ makaleler/dergi19/14-17.pdf [Erişim tarihi 09.06.2020].

Yağdı K. H.R. Ekingen, 1993. Güney Marmara ve Geçit Bölgeleri için makarnalık buğday çeşitlerinin geliştirilmesi. Makarnalık Buğday ve Mamülleri Simpozyumu, 30 Kasım-3 Aralık 1993, Ankara. s. 253-261. Yağımlı, M. Ergin, H. 2017. Türkiye'de İş Kazalarının Üstel Düzeltme Metodu ile Tahmin Edilmesi. Marmara Fen Bilimleri Dergisi 2017, 4, 118-123

Yalvaç K. Bozkurt B. Uyanık M. Yazar S. Koç C. Gümüş A. Atlı A. 2010. AB' de ve Türkiye'de sertifikasyon ile ilgili uygulamalar ve tohumluk üretimi. Makarnalık buğday mamulleri Konferans Bildiri Kitabı. 17-18 Mayıs 2010 Şanlıurfa. Yamane T. 1967. Elemantary sampling theory. printice hall $1 \mathrm{nc}$, englewood cliffs, New Jersey 